$5,421-434,2012$

\title{
Preventive strategy in response to climate change and infrastructural failures for Jakarta slum dwellers
}

V. Pooroe ${ }^{1}$ and I. Prabaharyaka ${ }^{2}$

${ }^{1}$ Amrta Institute for water literacy, Jl. Wologito Tengah II No. 16 Kembangarum, Semarang Barat Semarang 50148, Central Java, Indonesia

${ }^{2}$ Insulinde Research Institute, Sukamenak Indah P-36 Bandung 40227, West Java, Indonesia

Received: 31 May 2012 - Accepted: 16 June 2012 - Published: 6 August 2012

Correspondence to: V. Pooroe (vincent_p@rocketmail.com)

and I. Prabaharyaka (iprabaharyaka@gmail.com)

Published by Copernicus Publications on behalf of the Delft University of Technology.

Preventive strategy in response to climate change

V. Pooroe and

I. Prabaharyaka

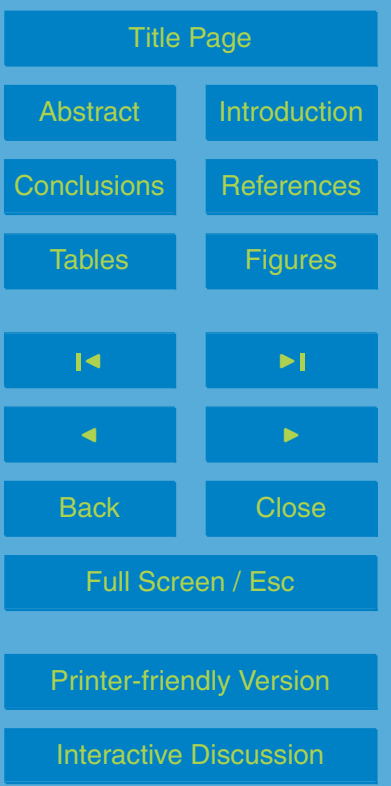

Interactive Discussion

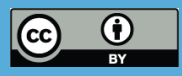




\section{Abstract}

Jakarta is a city with unpredictable yet annual water shortages, both during the dry and wet season, which disproportionately affect the urban poor. One possible solution is to redevelop the existing water supply system which is now working in one of the largest 5 slum area in Penjaringan, North Jakarta. This system is equipped with a large meter, the Master Meter, to record the communal water consumption and individual meters to record household consumptions. The Community Based Organization uses, operates, and maintains the system based on agreement with water users. Improvement of the Master Meter is achieved by harvesting uncollected rain water during the wet season influent water quality. This paper aims to provide a preventive strategy in response to climate change and infrastructural failures based on a case study of community-based water supply project in Penjaringan, Jakarta.

\section{Introduction}

15 Regionally, an analysis of climate change trends clearly suggests that Jakarta is experiencing a higher flow of water during the wet season and increasing drought during the dry season (Susandi, 2006; Avia, 2007; Sabar, 2010). In terms of climate change vulnerability, Jakarta emerged as the most vulnerable city in South East Asia (Yusuf and Francisco, 2010). Although water shortage occurs annually in Jakarta, it is unpredictable and attributed to different causes beginning with infrastructural failures to reduced supply from the catchments upstream due to less rainfall. Nevertheless the main reason for the water shortage is arguably infrastructural failures, while climate change merely amplifies it. The worst case of infrastructural failure was in September 2011 when half of Jakarta residents barely recovered from a water shortage due to damage at the Kali Malang retention basin (Jakarta Globe, 2011).
$5,421-434,2012$

\section{Preventive strategy in response to climate change \\ V. Pooroe and \\ I. Prabaharyaka}

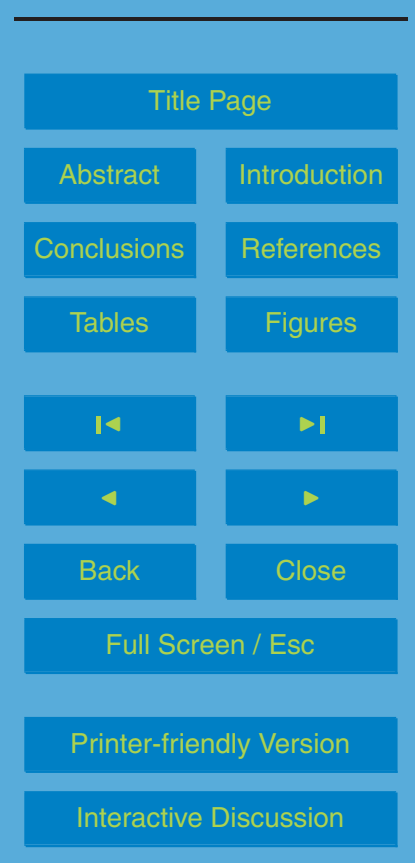


Jakarta's water utilities currently produce $493.59 \times 10^{6} \mathrm{~m}^{3} \mathrm{yr}^{-1}$ of water, which supplies only $62.31 \%$ of the water demand to 9.59 million residents the number of which is growing annually by $1.4 \%$ (Badan Regulator, 2010; Biro Pusat Statistik, 2011). This percentage of demand is reduced considering that more than $40 \%$ of the distributed 5 water is leaked and categorized as Unaccounted-for Water (UFW). Insufficient supply and limited access to clean water largely affects the lives of low income groups in Jakarta, particularly slum dwellers living in the city's low-income settlements. These people are often not connected to the piped water system and can potentially pay up to 50 times more for bottled water or water from intermediary water vendors.

10 The case study in this paper is based on the authors' experiences conducting a participatory action research project in Penjaringan. Since 2009, a community-based water supply system was implemented by Mercy Corps Indonesia, a non-governmental organization (NGO) through a collaborative venture between PT. Perusahaan Air Minum Lyonnaise Jaya (PALYJA), the private water provider in Jakarta, North Jakarta City 15 Administration and the Community Based Organization (CBO), named Jaka Tirta, to improve access to clean water for poor people. In terms of the adopted technology, the Master Meter is a roof- and ground tank reservoir equipped with a large meter to record communal water usage. In addition, each household has a household meter for comparison with the master meter recording. This system increases the monitor20 ing capacity of the Jakarta private water company (PALYJA), reduces the unit cost of water for low-income residents, and increases the access to piped water for people in low-income urban settlements.

The objective of this paper is to assess the opportunity of improving the capacity of the community-based water supply system to adapt to future trends in climate change. 25 Before discussing the case study, we elucidate the consquences of climate change for urban water supply in Jakarta which is also subject to infrastructural failures. We describe the socio- economic profile of Penjaringan and discuss both the successes and setbacks in designing, implementing, and sustaining a community-based water supply system in a dense, low- income, urban settlement. We then address the possible
$5,421-434,2012$

\section{Preventive strategy in response to climate change \\ V. Pooroe and \\ I. Prabaharyaka}
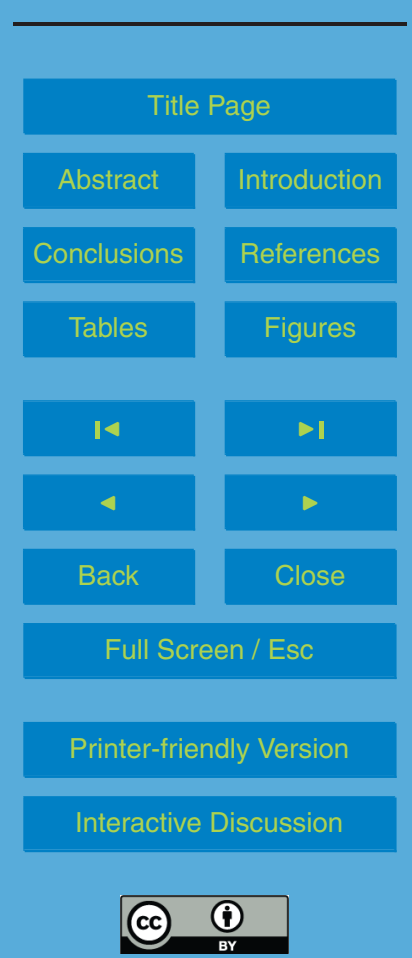
socio-technological improvements. Finally, the paper concludes with recommendations on improving community-based water supply projects to adapt to climate change, using our case study as a model.

\section{Methodology}

5 First, we conducted a desktop literature review of urban water and climate change studies. To enrich our findings, we interviewed a key actor in Jakarta urban water management, Mr. Firdaus Ali, the Board Member for Technical Affairs, Jakarta Water Regulatory Body. Primary data is extracted from a community survey on participatory monitoring of water quantity. Second, we analyze data given by the Water Regulatory

10 Body who officially collect a series of non digitized urban water supply data for accounting purposes. The comparison of raw and treated water has been made since 2006 in which the indication of infrastructural failures and the impact of ecosystem stress are apparent. We then compared data from the piped water system and Master Meter to analyze the trend of water shortage during the dry and wet season. Based 15 on this analysis, we proposed a socio-technical improvement of the Master Meter and possible stakeholder partnerships within the framework of Jakarta urban water supply.

\section{Discussion}

For the last century, Jakarta is experiencing apparent climate change from which geophysicists confirmed the consistently increasing air temperature in Jakarta for the period 1901-2002 (Avia, 2007). Subsequently, hydrologists confirmed the trend of the extremes of minimum/maximum discharge during the dry and wet season (Sabar, 2010) which is complementary to the phenomenon of a positive-negative anomaly in rain-fall intensity (Susandi, 2006).

In the light of integrated water management, quantity and quality both affect availability. The main problem at Jatiluhur Dam is competition between the portions of water

\section{Preventive strategy in response to climate change \\ V. Pooroe and \\ I. Prabaharyaka}

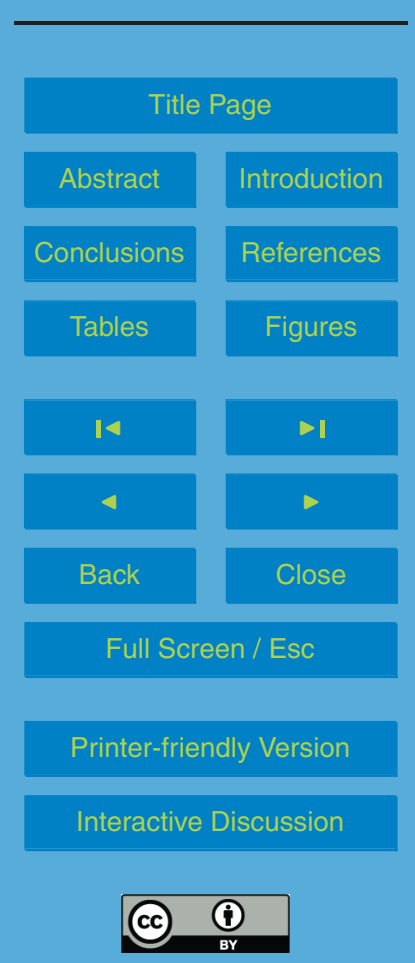


quantity for raw water supply and for agricultural demands (Katiandagho, 2007). On the one hand, when the water level above the dam is severely decreasing during the height of the dry season, raw water supply will be affected disproportionately due to the very small quota of water available. In the overall water balance, the percentage of 5 water channeled to Jakarta for supply purposes is relatively small (6\%) compared to the proportion of water directed from the dam for agricultural use, which accounts for approximately $90 \%$ of total water balance. On the other hand, the ecosystem stress along the West Tarum Canal mainly comes from fixed point sources of industrial and domestic waste (Fares and Ikhwan, 2001). During weather transition period, the mixing 10 of the Tarum Canal water with the three bypassing main rivers induces high levels of turbidity. This alarming water quality results in more than half of the raw water is having to be wasted because the treatment cost is increasing with decreasing water quality (see Fig. 1).

Compared to other groups of urban dwellers, the urban poor is the most sensi15 tive group which indirectly suffers most from the effects of climate change (Alam and Rabbani, 2007). Since most slum dwellers are serviced mainly by water vendors who charge a higher unit price than the piped water suppliers, water shortage events are likely to lead to a volatile and exorbitant unit price of water in the informal market. During flooding events, water is abundant but there is a higher epidemiological risk of water-borne diseases due to contamination or spoiled water storage.

Penjaringan is one of the largest slum settlements and poverty pockets in Jakarta. Based on the preliminary survey, on average Penjaringan households spent more money than they made per month (MercyCorps, 2006). Each household spent around IDR 90000 per month for water (approximately USD 10) which constitutes around $8.4 \%$ of their total expenditure (MercyCorps, 2008). This percentage exceeds the government's basic principle of a maximum of $4 \%$ of a household's average income as stipulated by the Ministry Regulation (Badan Regulator, 2010b). In order to be connected with the piped water system, the water utilities require the households in the settlement to present titles or certificates of their lands beforehand. This was difficult to
$5,421-434,2012$

\section{Preventive strategy in response to climate change \\ V. Pooroe and \\ I. Prabaharyaka}

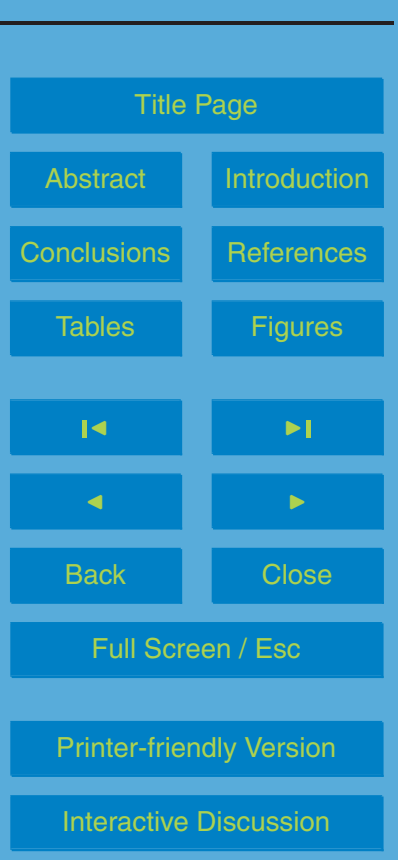

425 
be achieved in total since only $62 \%$ of residents were able to show proof of Land Tax payment, and only $47 \%$ of residents have been resident for more than $20 \mathrm{yr}$.

As a response to this situation, a pilot of a participatory research action project was launched in 2009 in Neighborhood 12, Penjaringan, in the form of a communal water 5 supply system to which previously unregistered households can be connected under the umbrella of a community based organization (CBO) named Jaka Tirta. This system brings water from PALYJA to a communal water storage facility. The water is then distributed to individual households, through a piped system, to three zones. In term of design, Master Meter is a water supply installation with roof- and ground tank reservoir o equipped with a large meter to record communal water usage.

This project has been made possible by the active participation of stakeholders involved in urban water supply. The Social Welfare Division of North Jakarta Government has given support by issuing a recommendation letter to ensure the legality of this project. The Master Meter was constructed by PALYJA at a cost of IDR 33.1 million 15 supported by 58 household subscriptions. Each household contributed IDR 200000 and the project provided IDR 400000 per household. By adding $30 \%$ for the operational and maintenance costs, the water users' tariff has been set by a CBO meeting at IDR 4700 for 5500 per cubic meters (Pooroe and Prabaharyaka, 2010).

During the lifetime of the project, intermittent water supply has triggered both techni20 cal and social problems. While the initial design capacity set to $24 \mathrm{~m}^{3} \mathrm{~d}^{-1}$, PALYJA has only supplied nearly of this amount for a less than 24-h service. The worst situation happened on June 2010 when PALYJA only supplied $10.3 \mathrm{~m}^{3} \mathrm{~d}^{-1}$ or 36.9 lcapita $^{-1} \mathrm{~d}^{-1}$ (see Fig. 3). During this event, users did not receive their daily need for water and had to allocate extra money and energy to buy water from informal water vendors at 25 a grossly inflated price, sometimes up to $200 \%$ of the normal informal market price. This condition triggered disputes and distrust among users of the system and the CBO leadership. Several members came to the neighborhood leader and stated their intention to withdraw from the CBO membership.
$5,421-434,2012$

\section{Preventive strategy in response to climate change \\ V. Pooroe and \\ I. Prabaharyaka}

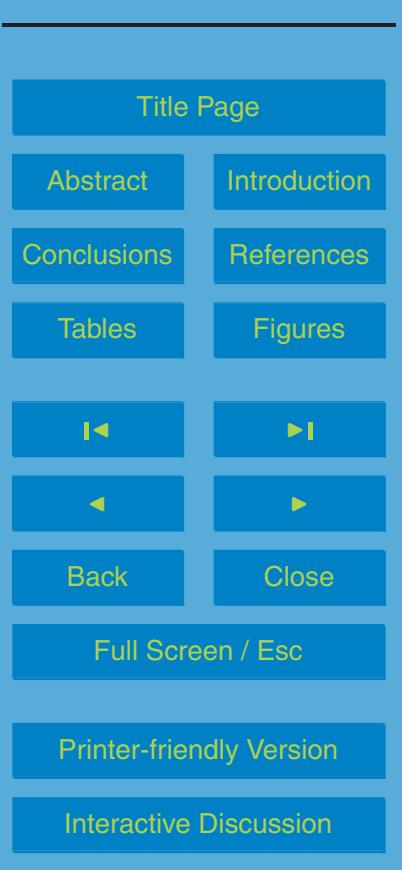


In response the $\mathrm{CBO}$ formulated a solution based on agreed conditions encouraging the principal of sharing. The $\mathrm{CBO}$ and water users agreed to divide each zone (zone I to zone III) into two sub-zones. The operator for each zone provided water to each of the sub-zones for one hour in turn. The supply of water to each zone and sub-zone was 5 managed using a written time schedule and monitored by the sub-zone coordinators. Although social unrest during water shortages was solved by the CBO in this way, it is important to develop a strategy for intervention as a preventive measurement.

\section{Results}

To date, 56 households are registered as water users. Each person in every household 10 receives on average more than $50 \mathrm{Id}^{-1}$, which is more than the basic minimum water consumption (Gleick, 1996). In the 13 months of water consumption from June 2010 to July 2011, there were 3 months with less than $50 \mathrm{Id}^{-1}$ and this occurred in both wet and dry seasons (June, July, and September). In the light of climate change, water supply of the Master Meter follows the regional rainfall trend in which a positive anomaly, that

15 is, a higher rainfall during the height of the wet season, in February/March is more apparent. This is consistent with the data on water sold monthly by PALYJA which shows that there was less water sold during the wet season (Badan Regulator, 2010a). Consequently, this is an opportunity to improve the performance of the Master Meter by harvesting uncollected rain water to reduce the probability of water shortage, to 20 recharge and to increase daily water consumption.

We thus propose an upgraded version of Rainwater Harvesting as a socio-technical improvement option to improve the Master Meter capacity to capture and store water as well as a means of flood risk reduction. This design accommodates additional features of slow sand filtration, germicidal UV lamp, and limestone to improve the influent 25 water quality. Consequently, there is a need to enlarge the ground tank to adapt to an
additional water influent from Rainwater Harvesting. Assuming $30 \mathrm{~m}^{2}$ of roof area, this
$5,421-434,2012$

\section{Preventive strategy in response to climate change \\ V. Pooroe and \\ I. Prabaharyaka}




design will allow up to $8000 \mathrm{Imonth}^{-1}$ of additional water during the wet season, which is going to be stored in a $0.4 \mathrm{~m}^{3}$ tank.

The addition of Rainwater Harvesting requires investment; a stakeholder partnership needs to be formed to support this new system. Rubin and Rubin (2001) explain 5 that such a partnership scheme is socially framed in the form of shared roles and the responsibility to cover the amount of investment needed. In addition to this, the partnership scheme plays an active role in social change activities. For example, the CBO can be actively involved in networking and campaigning with other civil society organizations related to urban water supply and at the same time look for opportunities for fundraising. On the other hand, the government can open up direct access to infrastructure development funds as well as encourage PALYJA by providing technical assistance for community development work. Intervention, in the form of a shared role and responsibility in terms of both kind and cash from each stakeholder, must be socially framed as described in Table 1.

\section{Conclusions}

Although climate change contributes to water shortage, infrastructural failures contributes more to the unpredictable annual water shortages and disproportionately impact the urban poor who have to pay an even more expensive price for water from informal vendors. Climate change is both an opportunity and threat. Higher rainfall during the wet season is an opportunity to improve water supply by enhancing the performance of the Master Meter by harvesting uncollected rain water to reduce the probability of water shortage, to recharge the water storage, and to increase daily water consumption. However, this paper has not addressed the extreme low rainfall during the dry season. Future research should be directed to alternative socio-technical imimplementation in the physical setting of a slum settlement.

$5,421-434,2012$

\section{Preventive strategy in response to climate change \\ V. Pooroe and \\ I. Prabaharyaka}

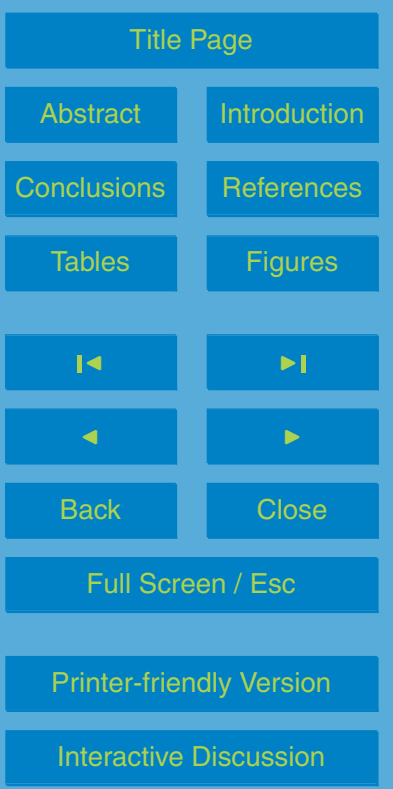




\section{References}

Alam, M. and Rabbani, M. D. G.: Vulnerabilities and responses to climate change for Dhaka, Environ. Urban., 19, 81-97, 2007.

Avia, L. Q.: Kondisi Iklim Jakarta pada Masa Lalu dan Masa Kini (Climate Condition in Jakarta, past and future), in: Prosiding Seminar Nasional Pemanasan Global dan Perubahan Global; Fakta, Mitigasi, dan Adaptasi (Proceedings of Global Warming and Change Seminar: Fact, Mitigation and Adaptation), Lembaga Antariksa dan Penerbangan Nasional, 2007.

Badan Regulator: Laporan Bulanan Kedua Operator dari PALYJA dan AETRA (Second Month Report from Private Water Operator, PALYJA and AETRA), Badan Regulator Perusahaan Air Minum Daerah Khusus lbukota Jakarta (Water Supply Regulatory Body of Jakarta Special Province), Jakarta, 2010a.

Badan Regulator: Target Teknis dan Standar Pelayanan yang Disepakati antara PAM Jaya dan Kedua Mitra Swasta (Technical Targets and Agreement of Standard Water Services between PAM Jaya and Private Operators), Badan Regulator Perusahaan Air Minum Daerah Khusus Ibukota Jakarta (Water Supply Regulatory Body of Jakarta Special Province), Jakarta, 2630, $2010 \mathrm{~b}$.

Desakota Study Team: Re-imagining the rural-urban continuum, research gap assessment, Institute for Social and Environmental Transition, Nepal, 2008.

Fares, Y. R. and Ikhwan, M.: Conceptual modeling for the management of the Citarum/Ciliwung Basins, Indonesia, J. Environ. Hydrol., 9, 1-13, 2001.

Gleick, P. H.: Basic water requirements for human activities: meeting basic needs, Water Int., 21, 83-92, 1996.

Hidayati, R.: Kajian Iklim Kota Jakarta, Perubahan dan Perbedaan dengan daerah sekitarnya (Jakarta City Climate Study: Changes and Differences with Surrounding Area), Agriclimatology Program, Postgraduate School of Bogor Agricultural University, 1990.

Jakarta Globe, Piece of Mind: For Many the Water Crisis Is Not Over Yet, 8 September, available at: http://www.thejakartaglobe.com/lifeandtimes/ piece-of-mind-for-many-the-water-crisis-is-not-over-yet/464186, 2011.

Katiandagho, T. M.: Model Pengelolaan Sumber Daya Air dalam Kompetisi antar Sektor di Wilayah Hilir Daerah Irigasi Jatiluhur: Pendekatan Optimasi Dinamik (Modelling of Water Resource Management in Sectoral Competition on Upstream Jatiluhur Irrigation Area: Dynamic Optimization Approach), Postgraduate School of Bogor Agricultural University, 2007.
$5,421-434,2012$

\section{Preventive strategy in response to climate change \\ V. Pooroe and \\ I. Prabaharyaka}

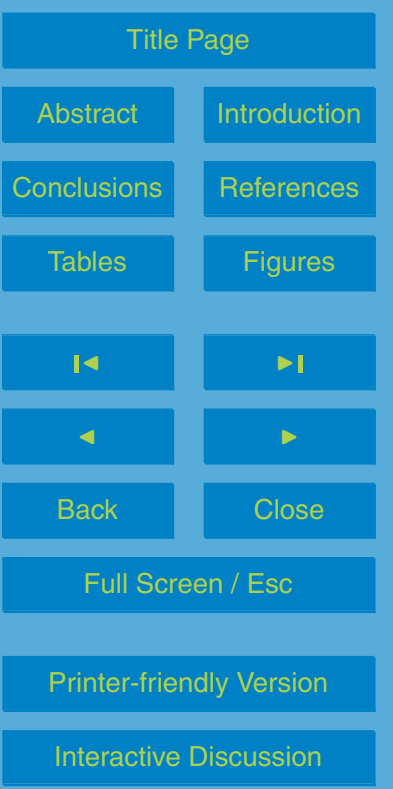


MercyCorps: Jakarta Urban Livelihoods Study, MercyCorps Indonesia, 2006.

MercyCorps: Baseline Survey on Household Water Consumption and Expenditure, MercyCorps Indonesia, 2008.

Pooroe, V. and Prabaharyaka, I.: Participatory urban water supply in Jakarta, in: Water Resources and Development in South East Asia, South East Asia Centre, Buffalo State University, New York, 232-245, 2010.

Rubin, H. J. and Rubin, S. I.: Community Organizing and Development, 3rd edn., Pearson Education Company, Massachusets, 205-401, 2001.

Sabar, A.: Penataan Ruang Berbasis Pasar versus Sumber Air Berkelanjutan (Market Based Spatial Planning versus Sustainable Water Resources), in: Focus Group Discussion Rekayasa Teknis Penataan Ruang terkait Intrusi Air Laut dan Reklamasi (Technical Engineering of Spatial Planning related to Sea Water Intrusion and Reclamation), Kementerian Koordinator Bidang Perekonomian Indonesia (Department of Economic Affair, Government of Indonesia), 2010.

Susandi, A.: Perubahan Iklim Wilayah DKI Jakarta: Studi Masa Lalu Untuk Proyeksi Mendatang (Climate Change of Jakarta Special Province: Studying Past for the Future Projection), Proceedings of the 31st Annual Scientific Meeting HAGI, 2006.

Yusuf, A. A. and Francisco, H. A.: Climate Change Vulnerability Mapping for Southeast Asia, Final Mapping Report, Economic and Environment Program for Southeast Asia, Canadian

\section{$5,421-434,2012$}

\section{Preventive strategy in response to climate change \\ V. Pooroe and \\ I. Prabaharyaka}

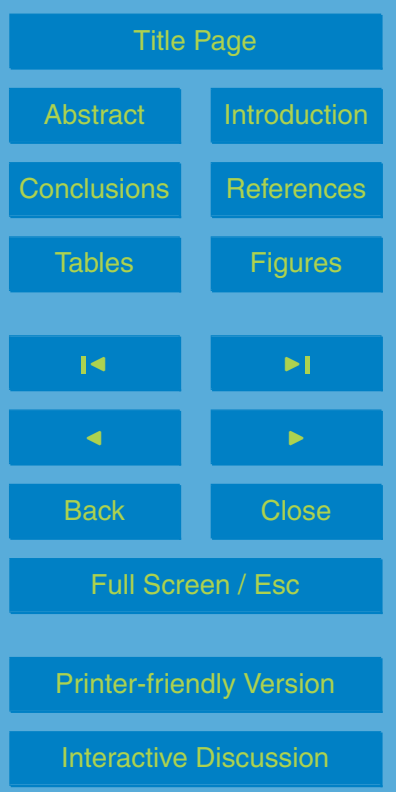


Table 1. Role and responsibility in stakeholder partnership.

\section{Institution}

Jakarta Municipal Government District and Subdistrict of Penjaringan. Public Work Agency; Water Management Body.

Water Utility-PALYJA (Perusahaan Air Minum Lyonnaise Jakarta Raya)

Community Based Organization (CBO)

\section{Role and Responsibility}

- Direct access to the infrastructure development fund which is normally channeled through different channels such as Musyawarah Perencanaan Pengembangan Kota (The BottomUp Process of Urban Community Discussion in City Development Planning), National Program for Community Empowerment, etc.

- Ensuring a guarantee for the community based organization to apply for micro-credit mechanism.

- Validating the technical plan, together with PALYJA.

- Cooperating with PALYJA in studying the technical feasibility of rainwater harvesting.

- Technical assistance; contributing water supply expertise and facilities in the development of rainwater harvesting.

- Access for capacity building related to the management of rainwater harvesting.

- Providing a cost-benefit analysis of rainwater harvesting and the possibility of adaptation and replication.

- Actively involved in networking and campaigning with other civil society organizations related to urban water supply and at the same time looking for opportunities for fundraising.

- Mobilizing local labor in the construction of rainwater harvesting facilities.

- Mobilizing water users to support the construction by providing logistic support.

- Conducting transparent and accountable financial management.
$5,421-434,2012$

\section{Preventive strategy in response to climate change}

V. Pooroe and

I. Prabaharyaka

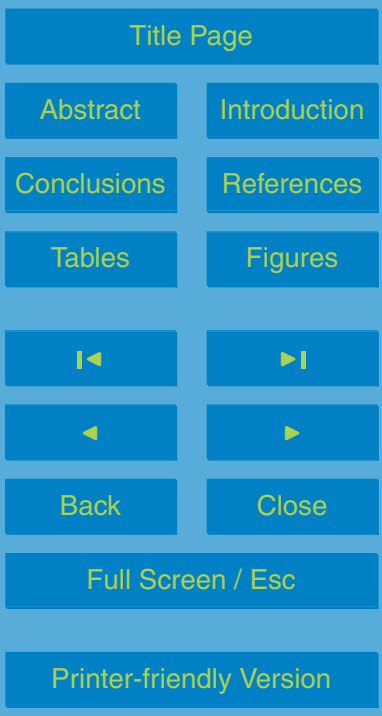

Interactive Discussion 
Percentage of Monthly Untreated Water of Palyja

(2006 - 2010)

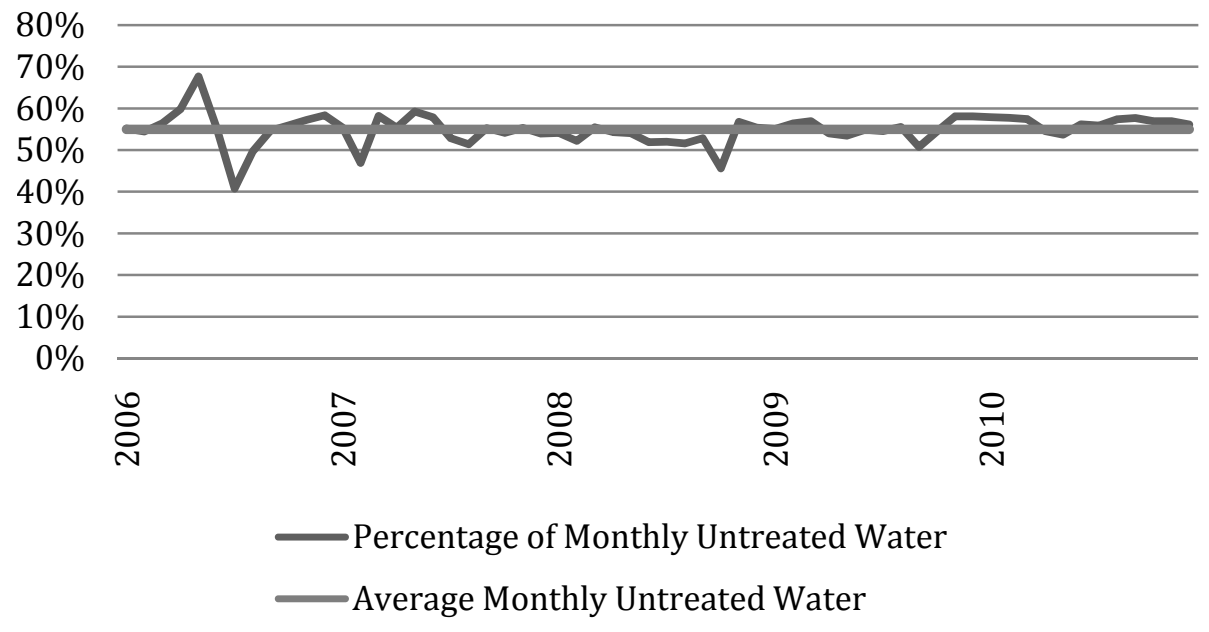

Fig. 1. Percentage of monthly untreated water of PALYJA (2006-2010), source: Water Regulatory Body (2010).

\section{$5,421-434,2012$}

\section{Preventive strategy in response to climate change \\ V. Pooroe and \\ I. Prabaharyaka}

\section{Title Page}

\section{Abstract}

Introduction

Conclusions

References

Tables

Figures

14

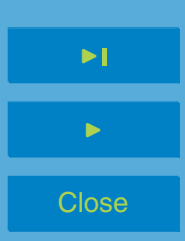

Back

lose

Full Screen / Esc

Printer-friendly Version

Interactive Discussion

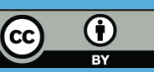






Fig. 2. Master Meter scheme, source: created by authors.

$5,421-434,2012$

\section{Preventive strategy in response to climate change \\ V. Pooroe and \\ I. Prabaharyaka}

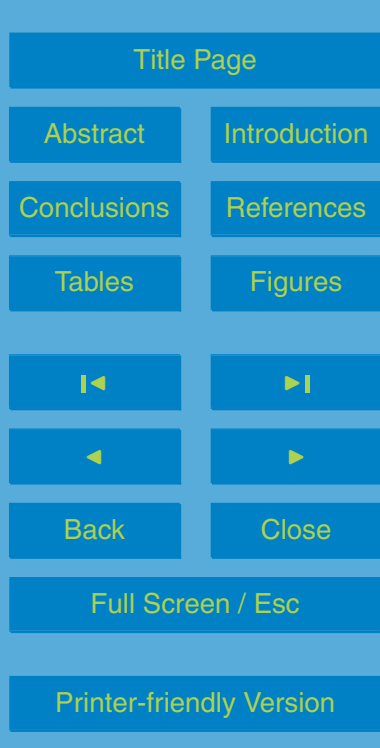

Interactive Discussion 


\section{$5,421-434,2012$}

\section{Preventive strategy in response to \\ climate change \\ V. Pooroe and \\ I. Prabaharyaka}

Master Meter;

\section{Household Daily Water Consumption}
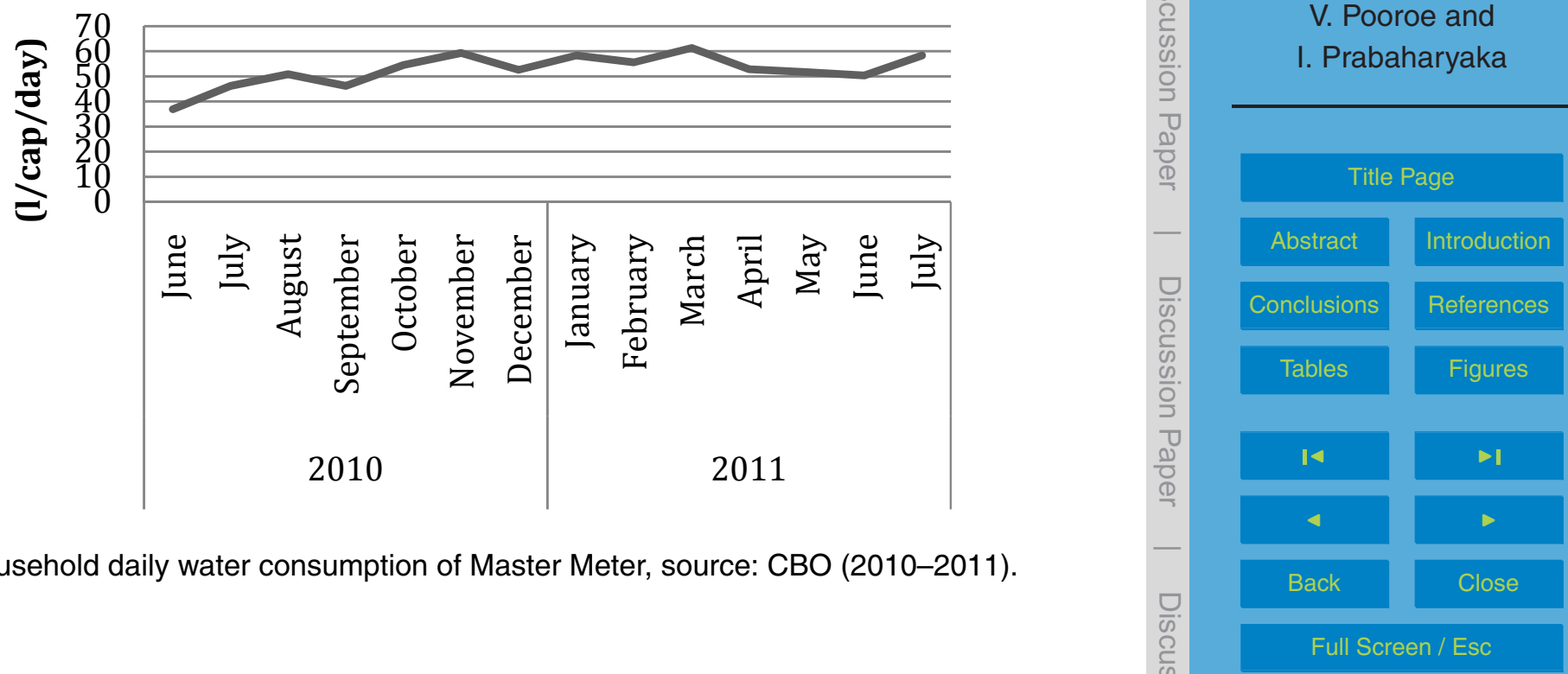

Printer-friendly Version

Fig. 3. Household daily water consumption of Master Meter, source: CBO (2010-2011). 